\title{
ВСТАНОВЛЕННЯ РЕЖИМІВ ТЕМПЕРАТУРНОГО ОБРОБЛЕННЯ М'ЯСА ІНДИЧКИ
}

\author{
Синиця О.В., аспірантка \\ Одеська національна академія харчових технологій, м. Одеса
}

Вимоги сучасного споживача до якості м'ясних продуктів та прагнення виробників залишатися конкурентоспроможними є основною причиною для розроблення нових високоякісних м'ясних продуктів.

У більшості технологій виробництва м'ясних виробів температурне оброблення є ключовою операцією. Від способів та параметрів температурного оброблення залежать показники якості, сенсорні властивості та техніко-економічні характеристики м'ясних продуктів.

Вибір температурно-часових параметрів температурного оброблення м'яса має бути індивідуальний враховуючи вид сировини, ї̈ фізико-хімічні особливості та бажані властивості готового продукту.

Перспективною сировиною для отримання високоякісних м'ясних виробів є м'ясо індички. Висока біологічна цінність та дієтичні якості індички дозволяють їй успішно конкурувати зі свининою та яловичиною. А значний вихід забійної тушки та велика частка м'язової тканини робить ії економічно привабливою у порівнянні з іншими видами домашньої птиці.

Вагомою проблемою при використанні індички у якості основної сировини в технології виробництва продукту є складність обвалювання в результаті особливостей ї̈ морфологічної структури. Вирішенням даної проблеми може стати використання попереднього температурного оброблення з подальшим обвалювання м'яса і використання вареної сировини в технології пастеризованих консервів.

У роботі представлені дослідження впливу температурно-часових режимів на структурно-механічні, фізико-хімічні, органолептичні та мікробіологічні показники гомілки індички. Проведено порівняльну оцінку гідротермічного оброблення м'яса при температурі гріючого середовища $65^{\circ} \mathrm{C}$ i $90{ }^{\circ} \mathrm{C}$ та показано позитивний вплив використання низькотемпературного тривалого гідротермічного оброблення на текстуру продукту та смакові властивості. Встановлено раціональність використання температури $65^{\circ} \mathrm{C}$ для термооброблення м'яса індички та підтверджено його мікробіологічну безпечність.

Ключові слова: м'ясо індички, температурне оброблення, денатурація, мікробіота, безпечність.

Формулювання проблеми. Технологія приготування будь-якого м'ясного продукту направлена на створення якісного, смачного та безпечного виробу. При цьому базовим критерієм якості при виготовленні $\epsilon$ забезпечення температурно-часових параметрів термічного оброблення [1].

В технологічному процесі центральне місце відводиться температурі та тривалості оброблення, в ході якого відбуваються зміни в текстурному профілі м'яса та досягається мікробіологіча безпечність продукту. Крім того, температурне оброблення збільшує засвоюваність м'яса [2].

Швидкість і ступінь цих змін залежить від кількості тепла, яке передається м'ясу та швидкості нагріву. Жорсткі режими термооброблення можуть викликати такі негативні зміни, як втрата поживної цінності білків і ліпідів, утворення токсичних сполук, погіршення сенсорних властивостей [3].

Параметри температурного оброблення повинні бути підібрані у відповідності з особливостями м'ясної сировини (вид м'яса, співвідношення тканин та білків) і бажаними показниками якості готового продукту.

На сьогоднішній день достатньо перспективною сировиною для виробництва м'ясопродуктів $\epsilon$ м'ясо індички. Продукти виготовлені з індички, мають високу харчову цінність, що характеризує здатність забезпечувати потреби організму в білках, ліпідах, а також в мінеральних речовинах і вітамінах. Крім того, індичка - одна 3 найбільших сільськогосподарських птахів і має значний вихід туші (понад 70 \%) та велику частку м'язової тканини (понад 60 \%), що дає перевагу при переробці в різні м'ясні продукти [4].

Білки м'яса індички є повноцінними, оскільки містять всі незамінні амінокислоти. При цьому жодна 3 амінокислот не є лімітуючої. Найбільше в м'ясі індички містяться лейцину $(8,14$ \% і 8,42 \% для 1-ї та 2-ї категорії відповідно) та лізину (8,39 \% і 8,94 \% для 1-ї та 2-ї категорії відповідно) [5].

Жир в індичці є легкозасвоюваним, адже в ньому містяться поліненасичені незамінні жирні амінокислоти, в основному представлені лінолевою кислотою та невеликою кількістю ліноленової.

Високий вміст вітаміну В 9 в м'ясі індички, який бере участь в генерації та підтримці в здоровому стані нових клітин організму, дозволяє віднести його за цим показником до функціональної продукції, так як його вміст в 100 г м'яса відповідає добовій нормі споживання [6].

М'ясо індички містить значну частину калію (212 мг/100 г) та фосфору (227,1 мг/100 г), а також таких мікроелементів як залізо (4,8 мг/100 г) і цинком $(2,8$ мг/100 г). За кількістю калію, м'ясо індички покриває близько 38 \% від добової його норми, а фосфору на 15 \%. Крім вищевказаних мінеральних речовин, в індич- 
ці 3 макроелементів також містяться кальцій, магній, натрій, фосфор і сірка, з мікроелементів - йод, мідь, марганець, селен, хром і фтор [7].

Зважаючи на високу харчову цініть м'яса індички, їі можна використати як основну сировину для виробництва нових видів кулінарних продуктів із застосуванням індивідуальних режимів температурного оброблення, які будуть мати відмінні споживчі характеристики та високу якість.

Прийнято вважати, що грудна частина птиці більш корисна за інші складові тушки, у тому числі за гомілки, оскільки містить менше жиру та калорій. Проте, в гомілках міститься значна частина колагену та більший вміст вітаміну А і заліза [8]. Продукти виготовлені з використанням даної частини туші будуть більш корисні для людей старшого віку, а також тих, які мають переломи кісток чи страждають на остеохондроз. Крім того, дана сировина має меншу вартість та є економічно доцільною.

Перспективними сьогодні є м'ясні продукти готові до вживання (ready to eat - RTE), до яких відносяться консерви. Завдяки герметичній упаковці вони здатні зберігатись тривалий час без погіршення якісних характеристик та безпечності. Пастеризовані консерви 3 м'яса птиці користуються великим попитом, оскільки при виробництві використовується біологічно цінна сировина.

Основна проблема використання гомілок індики полягає у складності обвалювання та в більшій жорсткості у порівнянні з філейною частиною або гомілками інших видів птиці.

Використання гідротермічного оброблення м'яса птиці на першому етапі технології виробництва пастеризованих консервів, дозволить раціонально використовувати м'ясну сировину (гомілки індички).

Аналіз останніх досліджень. Для сучасного споживача висока харчова та біологічна цінність, ніжний та соковитий смак м'ясного продукту є основними факторами, що впливають на його вибір. Одним із способів досягнення цих характеристик є виробництво продукту шляхом використання оброблення при низьких температурах протягом тривалого часу (low temperature long time - LTLT). Використання LTLT дає змогу виготовляти м'ясо з високими сенсорними якостями, ніжне та соковите [3,9].

Вперше позитивний вплив низькотемпературного тривалого оброблення на якісні показники готового продукту було вивчено в 1937 на прикладі виробництва продукту із яловичини. Подальші дослідження проведенні численними науковцями підтвердили сприятливий вплив LTLT на біологічну цінність, консистенцію, сенсорні показники та вихід готового продукту. Однак, дані роботи були зосереджені в більшості на дослідженні яловичини $[10,11]$ та свинини [12]. Робіт присвячених використанню низькотемпературного оброблення при виробництві м'ясних виробів із м'яса птиці досить мало.

Експериментальні дані [13] дослідження впливу низьких температур оброблення на напівфабрикати 3 філе індички в пароконвекційному апараті показали позитивний вплив на якісні характеристики готового продукту. Експериментальні зразки піддавали нагріванню в режимах «варіння парою» та «пароконвекційний режим при знижених температурах». Варіння при знижених температурах дозволило збільшити вихід виробів на $15 . .18$ \% у порівнянні з виробами обробленими традиційним способом. Дослідні зразки мали вищі органолептичні показники, м'ясо було соковитіше та ніжніше.

Аналіз доступної науково-технічної літератури показав, що велике значення має морфологічна частина тварини та співвідношення тканин м'яса [3]. Параметри температурного оброблення повинні бути підібрані враховуючи не тільки вид сировини, а й співвідношення м'язових та сполучно-тканинних білків. Зміни білків в процесі оброблення мають різноспрямований характер і залежать від температури та тривалості процеcy.

Температури, при яких відбувається денатурація різних фракцій білків м'яса, істотно розрізняються. Денатураційна зміна глобулярних білків (актину, міозин, актоміозину) починалася при температурі 45$50{ }^{\circ} \mathrm{C}$, а при досягненні $60{ }^{\circ} \mathrm{C}$ денатурує близько $90 \%$ молекул білків [3].

При нагріванні м'ясної сировини до температури 58-64 ${ }^{\circ} \mathrm{C}$ молекула колагену переходить зі спірального стану в випадково розгорнуту (аморфну) структуру. Необмежені колагенові волокна стискаються при нагріванні від 60 до $70^{\circ} \mathrm{C}$. Далі денатурація переходить у підвищену желатинізацію в зв'язку з розривом міжмолекулярних зв'язків через підвищення температури. Хоча повна желатинізація відбувається при температурі вище $65^{\circ} \mathrm{C}$, сучасні дані свідчать, що при повільному нагріві (швидкість не більше $5^{\circ} \mathrm{C} /$ хв.) більшість колагенових волокон в епімізії розчиняється при $59^{\circ} \mathrm{C}$ [14-16].

Час оброблення має також істотне значення. Дослідження диференціальної скануючої колориметрії показали майже повну денатурацію міозину у м'ясі після 3 год витримування при 53-54 ${ }^{\circ} \mathrm{C}$. При обробленні протягом 3 год і температурі близько $60{ }^{\circ} \mathrm{C}$ відбувається тривала денатурація колагену $[17,18]$.

У зв'язку з наявністю значної частини сполучної тканини в складі гомілки індички представляється актуальним вивчення впливу режимів температурного оброблення на зміну фізико-хімічних, структурномеханічних, органолептичних властивостей та показників безпеки обробленого м'яса.

Мета і задачі досліджень. Метою роботи є обгрунтування та встановлення раціональних режимів гідротермічного оброблення гомілок індички, як першого етапу виробництва пастеризованих консервів.

Для досягнення поставленої мети необхідно вирішити наступні задачі:

- визначити вплив температурно-часових параметрів гідротермічного оброблення на стан сполучної тканини та структурно-механічні показники м'яса індички;

- встановити вплив режимів оброблення на органолептичні показники; 
- вивчити показники мікробіологічної безпеки обробленого м'яса.

Матеріали і методи досліджень. Об'єктами дослідження були охолоджені гомілки індички ТМ «Інделіка». Дослідження проводились при температурі 65 та $90{ }^{\circ} \mathrm{C}$. Вибір температури $65^{\circ} \mathrm{C}$ обгрунтований дослідженнями впливу температур гідротермічного оброблення на м'ясо курчат-бройлерів за результатами яких вона є раціональною. У якості контрольного об'єкту виступали зразки обробленні при температурі $90{ }^{\circ} \mathrm{C}$. Критерієм закінчення тривалості оброблення були органолептичні показники, залишкова активність кислої фосфатази не більше 0,006 \% та легка можливість обвалювання м'яса.

Для визначення впливу температурного оброблення на функціонально-технологічні, структурномеханічні, мікробіологічні та органолептичні характеристики м'яса використовувалися загальноприйняті методи дослідження:

- $\quad$ розварювання колагену - по різниці вмісту оксипроліну в сирому і вареному м'ясі після видалення 3 нього продуктів гідролітичного розпаду колагену [19];

- $\quad$ кінематичну в'язкість бульйону визначали за допомогою капілярного скляного віскозиметра ВПЖ-2 (ГОСТ 10028-81) з діаметром капіляра 0,99 мм;

- структурно-механічні показники - за допомогою приладу Структурометр СТ-1 [20];

- втрати маси при термообробленні розрахунковим методом (зважуванням зразків до і після оброблення [21];

Органолептичні дослідження проводили використовуючи п'яти бальну шкалу оцінювання. В усіх зразках визначали такі показники, як зовнішній вигляд, консистенція, колір, запах та смак [21].

Кількість мезофільних аеробних і факультативно-анаеробних мікроорганізмів визначали відповідно до ГОСТ 8446:2015 Продукти харчові. Бактерії групи кишкової палички (БГКП) були визначні за допомогою середовища Кесслера відповідно до ГОСТ 998-81. Для визначення сульфітредукуючих клостридий використовували методику посіву $1 \mathrm{~cm}^{3}$ надосадової рідини продукту в середовище СЦС і Вільсона-Блера відповідно до ГОСТ 998-81. Патогенні мікроорганізми, серед яких Salmonella spp., визначали за допомогою посіву на селективне середовище і встановлювали їх серологічні і ферментативні властивості відповідно до ДСТУ ISO 6579. Staphylococcus aureus - згідно ГОСТ 10444.2-94.

Результати досліджень. Беручи до уваги важливість зміни сполучно-тканинних білків при встановленні температурно-часових параметрів гідротермічного оброблення індички, були проведені дослідження ступеня розварювання колагену, кінетичної в'язкості бульйону та встановлено тривалість оброблення (рис.1). Співвідношення м'яса до рідкої частини становило 1:2.

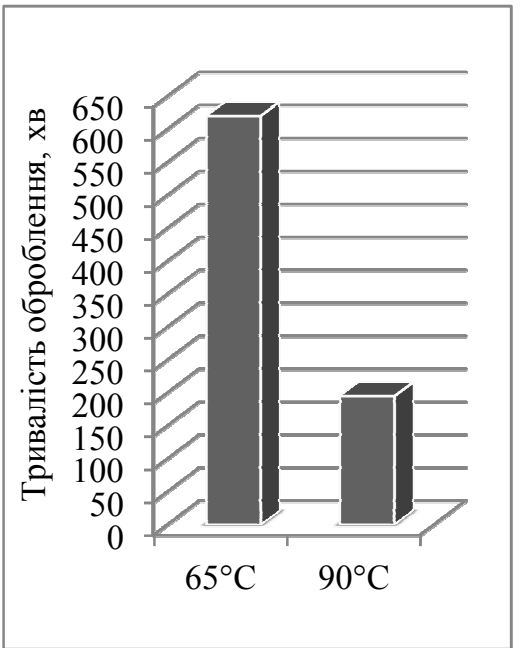

(a)

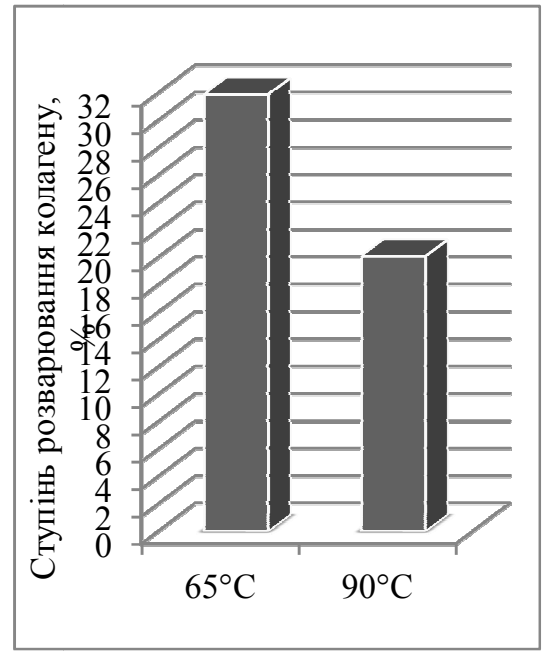

(б)

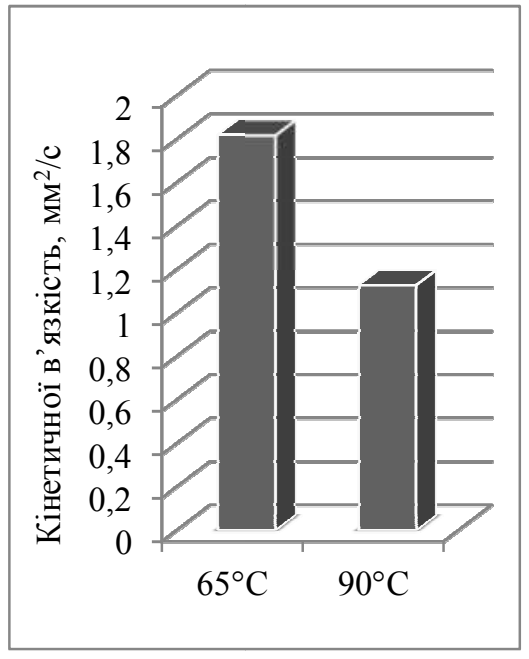

(B)

Рис. 1 - Вплив температури гідротермічного оброблення на (а) тривалість, (б) ступінь розварювання колагену та (в) кінетичну в'язкість бульйону

Оброблення при температурі $65{ }^{\circ} \mathrm{C}$ протягом 620 хв дозволило досягнути $31,9 \%$ розварювання колагену, що на 11,8 \% більше ніж при температурі оброблення $90{ }^{\circ} \mathrm{C}$. Кінетична в'язкість бульйону отриманого в результаті оброблення при $65^{\circ} \mathrm{C}$ вища ніж при $90{ }^{\circ} \mathrm{C}$.

Отримані результати ступеня розварювання колагену та в’язкості бульйону вказують на те, що тривале температурне оброблення при $65^{\circ} \mathrm{C}$ впливає на трансформацію колагену у більшій мірі ніж менш тривале при температурі $90^{\circ} \mathrm{C}$.

Важливою характеристикою м'яса є його органолептичні показники, особливо смак. Температура оброблення є причиною втрати маси м'яса та зміни структурно-механічних властивостей. На рис.2 представлені результати напруги зрізу та втрати маси, які характеризують жорсткість та міцність м’ясної системи, а на рис. 3 дана профілографа органолептичних оцінок гідротермічно обробленого м'яса індички.

Наукові праці, Том 85, випуск 1 


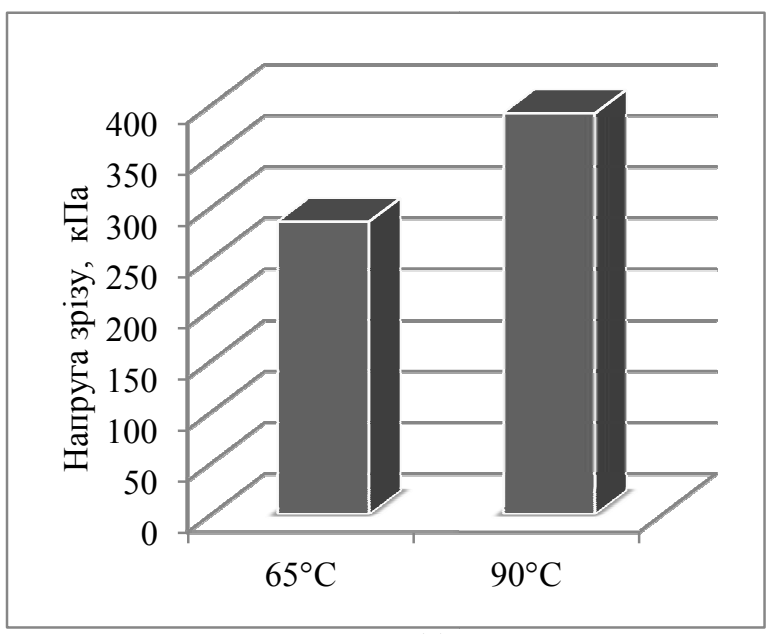

(a)

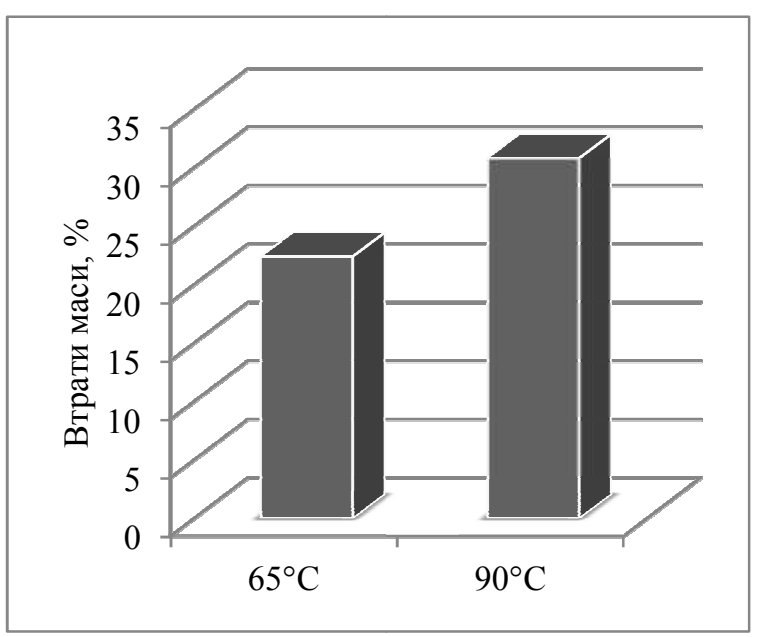

(б)

Рис. 2 - Вплив температури гідротермічного оброблення на (а) напругу зрізу та (б) втрати маси

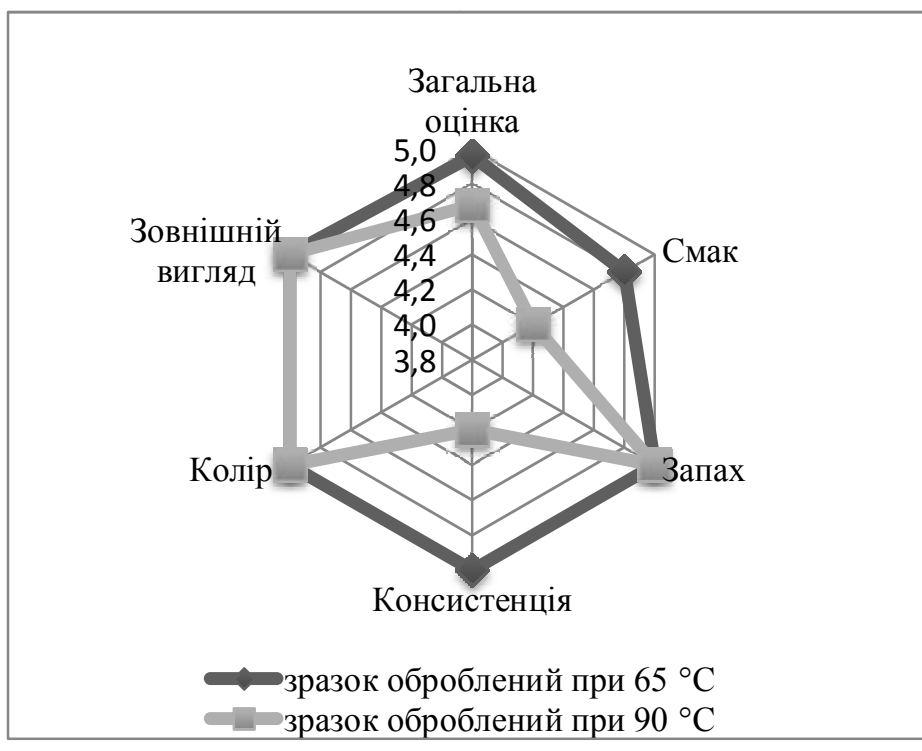

Рис. 3 - Профілограма органолептичних показників

3 результатів дослідження видно, що температура у більшій мірі призводить до зміни білків м'яса при нагріванні ніж тривалість оброблення. Графіки дослідження показують, що чим більша температура оброблення тим більші втрати маси та жорсткіше м'ясо. Так, при обробленні м'ясо при $65^{\circ} \mathrm{C}$ втрати маси на $11,3 \%$ менші ніж при $90{ }^{\circ} \mathrm{C}$.

Згідно результатів органолептичних досліджень зразки індички оброблені при температурі $65^{\circ} \mathrm{C}$ були більш привабливими для дегустаторів.

Дегустаційна комісія відзначила, що м'ясо оброблене при температурі $65^{\circ} \mathrm{C}$ дуже ніжне та соковите, а оброблене при $90^{\circ} \mathrm{C}$ більш жорстке та сухе.

За кольором та запахом зразки не відрізнялись. М'язова тканина була рівномірно забарвлена, світло-сірого кольору, який властивий вареному м'ясу індички.

Вирішальним показником при виробництві м'ясних продуктів $€$ їх мікробіологічна безпечність. Оскільки м'ясо було оброблено при низькій температурі необхідним було проведення дослідження ефективності температурного оброблення для інактивації мікроорганізмів. Отримані результати мікробіологічних досліджень представлені в табл.1. До температурного оброблення початкове забруднення м'яса було 520 КУО/г.

Таблиияя 1

\section{Результати мікробіологічних досліджень}

\begin{tabular}{|l|c|c|}
\hline \multicolumn{1}{|c|}{ Показники } & $\begin{array}{l}\text { Зразок оброблений при } \\
65{ }^{\circ} \mathrm{C}\end{array}$ & Зразок оброблений при $90{ }^{\circ} \mathrm{C}$ \\
\hline МАФАнМ, КУО в 1 г & 10 & 10 \\
\hline БГКП в 1 г. & не виявлено & не виявлено \\
\hline Сульфітредукувальні клостридії в 1 г & не виявлено & не виявлено \\
\hline Staphylococcus aureus в1 г & не виявлено & не виявлено \\
\hline Salmonella в 25 г. & не виявлено & ниявлено \\
\hline
\end{tabular}

Згідно представлених результатів можна стверджувати, що температурне оброблення при температурі $65{ }^{\circ} \mathrm{C}$ протягом тривалого часу є достатнім для досягнення мікробіологічної безпечності. Важливо відмітити, що після оброблення у зразках не було виявлено патогенних та умовно-патогенних мікроорганізмів. 
Оброблення при температурі $65^{\circ} \mathrm{C}$ позитивно вплинула на структурно-механічна і смакові властивості м'яса та викликає значно менші втрати маси, проте негативним моментом є велика тривалість такого оброблення. Метою подальших досліджень $є$ пошук шляхів скорочення тривалості оброблення при низькій температурі.

\section{Висновки}

1. Проведено порівняльні фізико-хімічні, структурно-механічні, мікробіологічні та органолептичні дослідження м'яса індички, які показали значну перевагу використання гідротермічного оброблення при низькій температурі $\left(65^{\circ} \mathrm{C}\right)$. Так, ступінь розварювання колагену на $11,8 \%$ більше у зразках оброблених при $65{ }^{\circ} \mathrm{C}$, що вкрай важливо для ефективного обвалювання м'яса та отримання необхідної структури продукту. При цьому, напруга зрізу на 106 кПа менша і свідчить про більшу ніжність м'яса обробленого при низькій температурі, що доповнюється кращими органолептичними оцінками зразків оброблених при $65^{\circ} \mathrm{C}$.

2. Встановлено раціональні режими гідротермічного оброблення гомілок індички для технології виробництва пастеризованих консервів, а саме 620 хв при температурі $65^{\circ} \mathrm{C}$.

3. На основі мікробіологічних досліджень доведено безпечність м'яса обробленого при встановлених температурно-часових параметрах гідротермічного оброблення.

4. Наступним етапом роботи є дослідження можливості скорочення тривалості гідротермічного оброблення при температурі $65{ }^{\circ} \mathrm{C}$ без погіршення якісних показників м'яса та безпеки готового продукту.

\section{References}

1. Dominguez-Hernandez, E., Salaseviciene, A., \& Ertbjerg, P. (2018). Low-temperature long-time cooking of meat: Eating quality and underlying mechanisms. Meat Science, 143, 104-113. doi:10.1016/j.meatsci.2018.04.032.

2. Qi, J., Li, X., Zhang, W., Wang, H., Zhou, G., \& Xu, X. (2018). Influence of stewing time on the texture, ultrastructure and in vitro digestibility of meat from the yellow-feathered chicken breed. Animal Science Journal, 89(2), 474-482. doi: 10.1111/asj.12929.

3. Tornberg, E. V. A. (2005). Effects of heat on meat proteins-Implications on structure and quality of meat products. Meat science, 70(3), 493-508. doi:10.1016/j.meatsci.2004.11.021.

4. Colak, H., Ugurluay, G., Nazlı, B., Bingol, E. B. (2011). The effect of humidity absorbing filters used as packing material on the shelf life of turkey meat. J. Fac. Vet. Med. Istanbul Uni., 37 (2), 107-116.

5. Gálvez, F., Domínguez, R., Pateiro, M., Carballo, J., Tomasevic, I., \& Lorenzo, J. M. (2018). Effect of gender on breast and thigh turkey meat quality. British poultry science, 59(4), 408-415. doi:10.1080/00071668.2018.1465177.

6. Barbin, D. F., Badaro, A. T., Honorato, D. C., Ida, E. Y., \& Shimokomaki, M. (2020). Identification of turkey meat and processed products using near infrared spectroscopy. Food Control, 107, 106816. doi:10.1016/j.foodcont.2019.106816.

7. Okuskhanova, E., Rebezov, M., Yessimbekov, Z., Suychinov, A., Semenova, N., Rebezov, Y., \& Zinina, O. (2017). Study of water binding capacity, $\mathrm{pH}$, chemical composition and microstructure of livestock meat and poultry. Annual Research \& Review in Biology, 1-7. doi:10.9734/ARRB/2017/34413.

8. Vinnikova L.H., Povarova N.M., Synytsia O.V. (2020). Osnovy ptakhivnytstva ta pererobky ptytsi. Kyiv:Osvita Ukraine, 216.

9. Christensen, L., Ertbjerg, P., Loje, H., Risbo, J., van den Berg, F. W., \& Christensen, M. (2013). Relationship between meat toughness and properties of connective tissue from cows and young bulls heat treated at low temperatures for prolonged times. Meat science, 93(4), 787-795. doi:10.1016/j.meatsci.2012.12.001.

10. Mortensen, L. M., Frøst, M. B., Skibsted, L. H., \& Risbo, J. (2015). Long-time low-temperature cooking of beef: three dominant time-temperature behaviours of sensory properties. Flavour, 4(1), 1-10.

11. Vaudagna, S. R., Sanchez, G., Neira, M. S., Insani, E. M., Picallo, A. B., Gallinger, M. M., \& Lasta, J. A. (2002). Sous vide cooked beef muscles: effects of low temperature-long time (LT-LT) treatments on their quality characteristics and storage stability. International journal of food science \& technology, 37(4), 425441. doi:10.1046/j.1365-2621.2002.00581.x.

12. Becker, A., Boulaaba, A., Pingen, S., Krischek, C., \& Klein, G. (2016). Low temperature cooking of pork meat-Physicochemical and sensory aspects. Meat Science, 118, 82-88. doi:10.1016/j.meatsci.2016.03.026.

13. Osipova Yu. N., Fedinishina E. Yu. (2016) Sovershenstvovanie tehnologicheskih parametrov resursosberegayuschey termicheskoy obrabotki myasa indeyki v parokonvektsionnyih apparatah [Improvement of technological parameters of resource-saving heat treatment of turkey meat in steam convection apparatuses.]. Regionalnyiy ryinok potrebitelskih tovarov: perspektivyi razvitiya, kachestvo i bezopasnost tovarov, osobennosti podgotovki kadrov, 80-82 (in Russian).

14. Brüggemann, D. A., Brewer, J., Risbo, J., \& Bagatolli, L. (2010). Second harmonic generation microscopy: A tool for spatially and temporally resolved studies of heat induced structural changes in meat. Food Biophysics, 5, 1-8. doi: 10.1007/s11483-009-9137-4. 
15. Zielbauer, B. I., Franz, J., Viezens, B., \& Vilgis, T. A. (2016). Physical aspects of meat cooking: Time dependent thermal protein denaturation and water loss. Food Biophysics, 11, 34-42. doi:10.1007/s11483-0159410-7.

16. Ertbjerg, P., \& Puolanne, E. (2017) Muscle structure, sarcomere length and influences on meat quality: A review. Meat Science, 132, 139-152. doi:10.1016/j.meatsci.2017.04.261.

17. Liu, J., Puolanne, E., \& Ertbjerg, P. (2014). Temperature induced denaturation of myosin: Evidence of structural alterations of myosin subfragment-1. Meat Science, 98, 124-128. doi:10.1016/j.meatsci.2014.05.013.

18. Berhe, D. T., Engelsen, S. B., Hviid, M. S., \& Lametsch, R. (2014). Raman spectroscopic study of effect of the cooking temperature and time on meat proteins. Food Research International, 66, $123-131$. doi:10.1016/j.foodres.2014.09.010.

19. Zhuravskaya N.K., Alekhina L.T., Opryashenkova L.M. (1985). Issledovanie i kontrol' kachestva myasa $i$ myasop-roduktov [Research and quality control of meat and meat products]. Moskva: Agropromizdat (in Russian).

20. Kabulov, B. B., Kakimov, A. K., Buyanova, I. V., Mustafaeva, A. K., \& Dzhilkisheva, A. G. (2014). Razrabotka metodiki opredeleniya napryazheniya sreza gotovyh produktov [Development of a methodology for determining the shear stress of finished products]. Sbornik nauchnyh trudov Mezhdunarodnoj nauchnotekhnicheskoj konferencii «Molodye uchenye-osnova budushchego mashinostroeniya i stroitel'stva», 135-139 (in Russian).

21. Antypova L.V., Hlotova Y.A., Rohov Y.A. (2001) Metody issledovaniya myasa i myasnykh produktov [Methods of research of meat and meat products]. Moskva: Kolos, 376.

\title{
TURKEY MEAT HEAT TREATMENT MODE SETTING
}

\author{
Synytsia O., postgraduate student \\ Odessa National Academy of Food Technologies, Odesa
}

The demands of the modern consumer for the quality of meat products and the intention of the producers to remain competitive are the main reason for the development of new high-quality meat products.

In most of meat production technologies, the heat treatment is a key operation. The quality parameters, sensor properties, and technical and economic characteristics of the meat products depend on the methods and parameters of heat treatment.

The selection of the temperature and time parameters of heat treatment of the meat shall be individual, taking into account the type of raw material, its physical and chemical properties and the desired properties of the finished product.

Promising raw material for high-quality meat products is turkey meat. The high biological value and dietary properties of the turkey make it possible to compete successfully with pork and beef. The significant yield of slaughtering bird and large share of the muscle tissue makes it economically attractive compared to other species of poultry.

An important problem in the use of turkey as the main raw material in the production technologies is the difficulty of dissection as a result of its morphological structure specifics. The solution to this problem may be application of pre-heat treatment with subsequent dissection of the meat and the use of boiled raw materials in the technology of pasteurized canned food.

The paper presents the studies of the influence of temperature and time modes on structural-mechanical, physico-chemical, organoleptic and microbiological parameters of the turkey thigh. A comparative evaluation of the hydrothermal meat treatment at a heating medium temperature of $65{ }^{\circ} \mathrm{C}$ and $90{ }^{\circ} \mathrm{C}$ is performed, and the positive effect of using low-temperature long-term hydrothermal treatment of product texture and eating qualities is demonstrated. The rationality of using the temperature of $65{ }^{\circ} \mathrm{C}$ for heat treatment of turkey meat is established, and its microbiological safety has been established.

Key words: turkey meat, heat treatment, denaturation, microbiota, safety.

\section{Список використаної літератури}

1. Dominguez-Hernandez, E., Salaseviciene, A. Ertbjerg, P. Low-temperature long-time cooking of meat: Eating quality and underlying mechanisms. Meat Science. 2018. No. 143. P. 104-113. doi:10.1016/j.meatsci.2018.04.032.

2. Influence of stewing time on the texture, ultrastructure and in vitro digestibility of meat from the yellow-feathered chicken breed / Qi, J et al. Animal Science Journal. 2018. Vol.89, No. 2. P. 474-482. doi: 10.1111/asj.12929.

3. Tornberg, E. V. A. Effects of heat on meat proteins-Implications on structure and quality of meat products. Meat science. 2005. Vol. 70, No. 3. P. 493-508. doi:10.1016/j.meatsci.2004.11.021. 
4. Colak, H., Ugurluay, G., Nazlı, B., Bingol, E. B. The effect of humidity absorbing filters used as packing material on the shelf life of turkey meat. J. Fac. Vet. Med. İstanbul Uni. 2011. Vol. 37, No. 2. P.107-116.

5. Identification of turkey meat and processed products using near infrared spectroscopy / Barbin, D. F., et al. Food Control. 2020. Vol. 107, No. 106816. doi:10.1016/j.foodcont.2019.106816.

6. Effect of gender on breast and thigh turkey meat quality / Gálvez, F., et al. British poultry science. 2018. Vol. 59, No. 4. P.408-415. doi:10.1080/00071668.2018.1465177.

7. Study of water binding capacity, $\mathrm{pH}$, chemical composition and microstructure of livestock meat and poultry / Okuskhanova, E., et al. Annual Research \& Review in Biology. 2017. P.1-7. doi:10.9734/ARRB/2017/34413.

8. Віннікова Л.Г., Поварова Н.М., Синиця О.В. Основи птахівництва та переробки птиці. Київ:Освіта України, 2020. 216 с.

9. Relationship between meat toughness and properties of connective tissue from cows and young bulls heat treated at low temperatures for prolonged times / Christensen, L., et al. Meat science. 2013. Vol. 93, No. 4. P. 787-795. doi:10.1016/j.meatsci.2012.12.001.

10. Long-time low-temperature cooking of beef: three dominant time-temperature behaviours of sensory properties / Mortensen, L. M., et al. Flavour. 2015. Vol. 4, No. 1. P. 1-10.

11. Sous vide cooked beef muscles: effects of low temperature-long time (LT-LT) treatments on their quality characteristics and storage stability / Vaudagna, S. R., et al. International journal of food science \& technology. 2002. Vol. 37, No. 4. P. 425-441. doi:10.1046/j.1365-2621.2002.00581.x.

12. Low temperature cooking of pork meat - Physicochemical and sensory aspects / Becker, A., et al. Meat Science. 2016. No. 118. P.82-88. doi:10.1016/j.meatsci.2016.03.026.

13. Осипова Ю. Н., Фединишина Е. Ю. Совершенствование технологических параметров ресурсосберегающей термической обработки мяса индейки в пароконвекционных апаратах. Региональный рынок потребительских товаров: перспективы развития, качество и безопасность товаров, особенности подготовки кадров. 2016. C. 80-82.

14. Second harmonic generation microscopy: A tool for spatially and temporally resolved studies of heat induced structural changes in meat / Brüggemann, D. A., et al. Food Biophysics. 2010. No. 5. P. 1-8. doi: 10.1007/s11483-009-9137-4.

15. Physical aspects of meat cooking: Time dependent thermal protein denaturation and water loss / Zielbauer, B. I., et al. Food Biophysics. 2016. No.11 . P. 34-42. doi:10.1007/s11483-015-9410-7.

16. Ertbjerg, P., \& Puolanne, E. Muscle structure, sarcomere length and influences on meat quality: A review. Meat Science. 2017. No. 132, P. 139-152. doi:10.1016/j.meatsci.2017.04.261.

17. Liu, J., Puolanne, E., \& Ertbjerg, P. Temperature induced denaturation of myosin: Evidence of structural alterations of myosin subfragment-1. Meat Science. 2014. No. 98. P. $124-128$. doi:10.1016/j.meatsci.2014.05.013.

18. Raman spectroscopic study of effect of the cooking temperature and time on meat proteins / Berhe, D. T., et al. Food Research International. 2014. No. 66, P. 123-131. doi:10.1016/j.foodres.2014.09.010.

19. Журавская Н.К., Алехина Л.Т., Опряшенкова Л.М. Исследование и контроль качества мяса и мясопродуктов. Москва: Агропромиздат, 1985, 296 с.

20. Разработка методики определения напряжения среза готовых продуктов / Кабулов Б. Б. и др. Сборник научных трудов Международной научно-технической конференции «Молодые ученые-основа будущего машиностроения и строительства». 2014. С. 135-139.

21. Антипова Л.В., Глотова И.А., Рогов И.А. Методы исследования мяса и мясных продуктов. Москва: Колос, 2001. 376 с.

Отримано в редакцію 10.03.2021

Прийнято до друку 14.06.2021
Received 10.03.2021

Approved 14.06.2021 